\title{
Prevalence and molecular characteristics of multi-resistant Escherichia coli in wild birds
}

\author{
Lina Merkeviciene, Irena Klimiene, Rita Siugzdiniene, Marius Virgailis, \\ Raimundas Mockeliunas, Modestas Ruzauskas \\ Lithuanian University of Health Sciences, \\ Microbiology and Virology Institute, Kaunas, Lithuania
}

Received June 1, 2017

Accepted April 3, 2018

\begin{abstract}
Humans and animals share the same bacterial species including the resistant ones. For that reason, epidemiological studies in domestic and wild animals should be performed on a regular basis. Wild, particularly migratory birds, should be investigated as potential carriers of antimicrobial resistant bacteria that can be spread globally in a short time. The aim of this study was to investigate the prevalence and to characterize multi-resistant Escherichia coli in wild birds. Three hundred and ninety two samples were obtained from different bird species including gulls (Larus spp.), mallards (Anas platyrhynchos), mute swans (Cygnus olor), as well as other species of birds. Phenotypical and genotypical resistance of $E$. coli was investigated. In total 60 isolates from 179 tested were resistant to three or more antimicrobial classes and treated as multi-resistant $(33.5 \%$; $95 \%$ CI $21.56-45.44)$; the isolates were obtained from gulls, mallards, swans, and rooks. All of the strains demonstrated resistance to aztreonam and cefpodoxime. The most frequent resistance prevalence of the above-mentioned isolates in vitro was also demonstrated to ampicillin (82\%), ampicillin/sulbactam $(68 \%)$, cefazolin $(66 \%)$, ceftriaxone $(55 \%)$, and ciprofloxacin $(47 \%)$. All E. coli isolates were susceptible to amikacin. The results of polymerase chain reaction confirmed the presence of the genes encoding resistance to beta-lactams, aminoglycosides, tetracycline, amphenicols, trimethoprim, and sulphonamides. Consequently, wild birds might constitute a potential hazard to human and animal health by transmitting multi-resistant $E$. coli strains to waterways and other environmental sources via bird faeces.
\end{abstract}

Antimicrobial resistance, genes, migratory birds

The resistance of bacteria to antimicrobials becomes a rising health problem in the world. The importance of wild birds as potential vectors of diseases has received renewed empirical interest recently, especially regarding human health. Escherichia coli is found in the environment, food and intestines of people and animals (Benskin et al. 2009; Wasinski et al. 2010). Due to their opportunistic and gregarious nature, gulls may be important reservoirs and vectors for anthropogenically derived faecal pathogens in coastal areas. Moreover, the migratory behaviour of birds has been proposed as a possible dissemination pathway of multi-resistant (MR) bacteria from human influenced habitats to remote places (Nelson et al. 2008; Guenther et al. 2012). Numerous wild bird species are attracted to untreated sewage, garbage dumps and manure, therefore, various pathogens such as Escherichia coli, Salmonella enterica and Campylobacter spp. might be prevalent in those birds (Quessy and Messier 1992; Hatch 1996; Moore et al. 2002; Fogarty et al. 2003; Waldenström et al. 2003). The aim of this study was to investigate the prevalence of and characterize the multi-resistant Escherichia coli in wild birds.

Address for correspondence:

Lina Merkeviciene

Microbiology and Virology Institute

Lithuanian University of Health Sciences

Tilzes g.18, Kaunas, 47181 Lithuania

Phone: +37062475685

E-mail: lina.merkeviciene@1smuni.lt

http://actavet.vfu.cz/ 


\section{Materials and Methods}

Samples and place

Three hundred and ninety two samples of wild bird faeces were collected in 2015-2017 using sterile cotton swabs with a transport medium (Transwab ${ }^{\circledast}$ Amies, UK) in city parks and the Kaunas city dump site. Cloacal samples from passerines were taken on a ringing station of Ventes Ragas $\left(55^{\circ} 20^{\prime} 28.1^{\prime \prime} \mathrm{N} 21^{\circ} 11^{\prime} 25.3^{\prime \prime} \mathrm{E}\right)$. Samples were delivered to the laboratory within $24 \mathrm{~h}$. In total, 392 samples were collected from 29 different species of birds: herring gulls (Larus argentatus), black-headed gulls (Chroicocephalus ridibundus), rooks (Corvus frugilegus), hooded crows (Corvus cornix), common ravens (Corvus corax), mallards (Anas platyrhynchos), mute swans (Cygnus olor), European kingfishers (Alcedo atthis), Eurasian nuthatchs (Sitta europaea), Eurasian siskins (Carduelis spinus), long-tailed tits (Aegithalos caudatus), black redstarts (Phoenicurus ochruros), blackcaps (Sylvia atricapilla), yellow-browed warblers (Phylloscopus inornatus), great tits (Parus major), dunnocks (Prunella modularis), European robins (Erithacus rubecula), common treecreepers (Certhia familiaris), wrens (Troglodytes troglodytes), barred warblers (Sylvia nisoria), bearded tits (Panurus biarmicus), chaffinches (Fringilla coelebs), chiffchaffs (Phylloscopus collybita), blackbirds (Turdus merula), song thrushes (Turdus philomelos), goldcrests (Regulus regulus), willow tits (Poecile montanus), common starlings (Sturnus vulgaris) and rock pigeons (Columba livia).

The ethical approval for this study was granted by the Lithuanian Environmental Protection Agency (permission number A4-8844).

\section{Bacteriological and susceptibility testing}

Material was inoculated onto McConkey Agar (Thermo Fisher, UK), for the screening of $E$. coli. Inoculated plates were incubated at $+37^{\circ} \mathrm{C}$ for $24 \mathrm{~h}$. After incubation, the plates were screened for presumptive colonies. The randomly selected separate colonies (one colony per sample) were then identified using "Microgen Gram-Negative Plus" biochemical identification system (Microgen, UK).

The initial antimicrobial susceptibility testing was performed using the disc diffusion method according to Kirby-Bauer and the results were interpreted according to the European Committee on Antimicrobial Susceptibility Testing (EUCAST) clinical breakpoints except for cefazolin as no interpretative criteria were set for this antibiotic. Therefore, the clinical breakpoints for cefazolin were used as per recommendations of the Clinical Laboratory Standards Institute (CLSI 2015). The following discs with antimicrobials (Thermo Fisher, UK) were used: ampicillin $(10 \mu \mathrm{g})$, gentamicin $(10 \mu \mathrm{g})$, ciprofloxacin $(5 \mu \mathrm{g})$, cefoxitin $(30 \mu \mathrm{g})$, tetracycline (30 $\mu \mathrm{g})$, imipinem $(10 \mu \mathrm{g})$ and chloramphenicol $(30 \mu \mathrm{g})$. Bacterial isolates resistant to three or more antimicrobial classes were then selected for the testing for minimal inhibitory concentrations (MIC's) using Sensititre ${ }^{\circledR}$ plates and ARIS $2 \mathrm{X}$ automated system (Thermo Scientific, UK) for amikacin, ampicillin, ampicillin/sulbactam, aztreonam, cefazolin, cefepime, cefotetan, cefoxitin, cefpodoxime, ceftazidime, ceftriaxone, ciprofloxacin, gatifloxacin, gentamicin, imipenem, nitrofuration, tobramycin and trimethoprim/sulphamethoxazole. Interpretation of the results was carried out using the manufacturer’s software (SWIN $\left.{ }^{\circledR}\right)$ adapted to the EUCAST clinical breakpoints.

\section{Molecular testing}

DNA (deoxyribonucleic acid) for molecular analysis was obtained after bacterial lysis. The cultures were grown on a Mueller Hinton Agar (Liofilchem, Roseto, Italy) for $24 \mathrm{~h}$ and afterwards a loopful of colonies was taken from the surface of the agar and transferred to phosphate buffered saline ( $\mathrm{pH}$ 7.3). The content was centrifuged for $5 \mathrm{~min}$. The supernatant was discarded and the pellet was re-suspended in TAE (tris-ethylenediaminetetraacetic acid) buffer. The suspension was heated using a thermomixer at $100{ }^{\circ} \mathrm{C}$ for $10 \mathrm{~min}$. Boiled suspension was transferred directly on ice and diluted by 1:10 in TAE.

The resistant E. coli isolates were tested by PCR (polymerase chain reaction) for the detection of genes encoding antimicrobial resistance (Table 1). The PCR mix (25 $\mu$ l) constisted of $12.5 \mu \mathrm{l}$ of the Dream Taq Green PCR Master Mix (ThermoFisher Scientific, Lithuania), $1 \mu \mathrm{l}$ of each primer, $2 \mu \mathrm{l}$ of the DNA template and $8.5 \mu \mathrm{l}$ of water. The PCR conditions were as follows: initial denaturation for $5 \mathrm{~min}$ at $94{ }^{\circ} \mathrm{C} ; 30$ cycles of $30 \mathrm{~s}$ at $94{ }^{\circ} \mathrm{C}, 60 \mathrm{~s}$ at the temperature indicated for each primer pair in Table $1,30 \mathrm{~s}$ at $72{ }^{\circ} \mathrm{C}$; and a final extension step of $7 \mathrm{~min}$ at $72{ }^{\circ} \mathrm{C}$.

The PCR products were determined by electrophoresis of $10 \mu \mathrm{l}$ of the reaction products on $2 \%$ agarose gel with $1 \mathrm{X}$ TAE buffer at $105 \mathrm{~V}$ for $50 \mathrm{~min}$.

\section{Data analysis}

Occurrences of multi-resistant (MR) isolates in faecal specimens were calculated by dividing the number of MR isolates by the total number of investigated specimens. For percentage estimates, Wilson (Score) $95 \%$ confidence intervals (CI 95\%) and their ranges for true population proportions were calculated. The MR occurrence was determined by bird species as well. Antimicrobial resistance rates for each tested antimicrobial were given as numbers of resistant per total number of MR isolates. 


\section{Results}

Resistant E. coli prevalence in bird faeces

During the study, E. coli resistant to one or more antimicrobials was recovered from 179 samples out of 392 tested $(45.6 \%$; 95\% CI 40.67-50.53). Resistant isolates were recovered only exceptionally from gulls, swans, ducks and rooks (Fig. 1). No resistant isolates were detected in the faeces of small passerine birds.

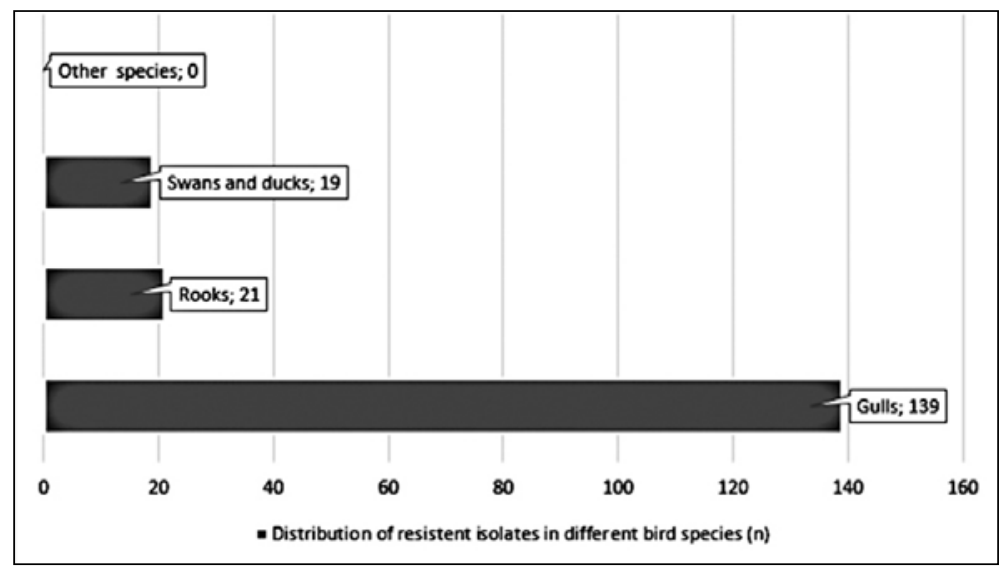

Fig. 1. Distribution of 179 E.coli isolates resistant to at least one antimicrobial in different wild bird species (n).

Antimicrobial susceptibility profiles

In total, 119 out of 179 isolates were resistant $(66.4 \%$; 95\% CI 57.91-74.89) only to a single or two antimicrobial agents, and 60 isolates were resistant to three or more antimicrobial classes $(33.5 \%$; 95\% CI 21.56-45.44). The multi-resistant (MR) isolates were obtained from gulls $(\mathrm{n}=51)$, swans $(\mathrm{n}=2)$, mallards $(\mathrm{n}=2)$ and rooks $(\mathrm{n}=5)$. (Plate II, Table 2) indicates the MIC distribution regarding multi-resistant E. coli isolates obtained from the wild birds.

All multi-resistant isolates were resistant to aztreonam and cefpodoxime. High resistance rates were also detected in vitro towards ampicillin (82\%), ampicillin/subactam $(68 \%)$, cefazolin $(66 \%)$, ceftriaxone $(55 \%)$ and ciprofloxacin $(47 \%)$. All E. coli isolates were susceptible to amikacin.

\section{Genes encoding resistance}

The genes encoding antimicrobial resistance to antimicrobials are presented in Table 3 .

The most prevalent genes were as follows: aphA1 (100\%), dfr5 (84.6\%), tetA, (85\%) and bla $_{\mathrm{TEM}}(66.6 \%)$, encoding resistance to aminoglycosides, trimethoprim, tetracycline, and beta-lactams, respectively. The negative results were shown for all isolates following the genes oxa5, per $_{1}$ and per $_{2}$.

\section{Discussion}

The emergence and spread of multi-resistant bacteria in natural environments constitute a serious impact on animal and human health. We have detected 60 multi-resistant $E$. coli isolates in wild birds out of 176 tested (33.5\%). The most prevalent resistance was detected towards aztreonam, cefpodoxime, other beta-lactams and fluoroquinolones. 
Table 1. Antimicrobial resistance genes tested and oligonucleotide primers used in the study.

\begin{tabular}{|c|c|c|c|c|}
\hline Primer name & Sequence $\left(5^{6}-3^{\circ}\right)$ & Size, bp and $\mathrm{t}\left({ }^{\circ} \mathrm{C}\right)$ & Target gene & Source \\
\hline blaTEM-F & GAGTATTCAACATTTTCGT & $857(50)$ & $b l a_{\mathrm{TEM}}$ & Van et al. (2008) \\
\hline blaTEM-R & ACCAATGCTTAATCAGTGA & & & \\
\hline blaSHV-F & TCGCCTGTGTATTATCTCCC & $768(60)$ & $b l a_{\mathrm{SHV}}$ & Ojdana et al. (2014) \\
\hline blaSHV-R & CGCAGATAAATCACCACAATG & & & \\
\hline oxa1-F & TCAACAAATCGCCAGAGAAG & $276(55)$ & bla $_{\mathrm{OXA}}$ group I & Bert et al. (2002) \\
\hline oxal-R & TCCCACACCAGAAAAACCAG & & & \\
\hline oxa3-F & TTTTCTGTTGTTTGGGTTTT & $427(52)$ & $b l a_{\mathrm{OXA}}$ group III & Bert et al. (2002) \\
\hline oxa3-R & TTTCTTGGCTTTTATGCTTG & & & \\
\hline$O X A 5$ group- $\mathrm{F}$ & AGCCGCATATTTAGTTCTAG & $644(56)$ & bla ${ }_{\mathrm{OXA}}$ group $\mathrm{V}$ & Bert et al. (2002) \\
\hline$O X A 5$ group- $\mathrm{R}$ & ACCTCAGTTCСТTTCTCTAC & & & \\
\hline$C T X-\mathrm{M}-\mathrm{F}$ & ATGTGCAGYACCAGTAARGT & $593(50)$ & $b l a_{\text {СТХ-м }}$ & Pagani et al. (2003) \\
\hline$C T X-\mathrm{M}-\mathrm{R}$ & TGGGTRAARTARGTSACCAGA & & & \\
\hline cmy $2-\mathrm{F}$ & GCACTTAGCCACCTATACGGCAG & $758(58)$ & $b l a_{\mathrm{CMY}}$ & Hasman et al. (2005) \\
\hline cmy2-R & GCTTTTCAAGAATGCGCCAGG & & & \\
\hline PER-1-F & ATGAATGTCATTATAAAAGCT & $927(48)$ & $b l a_{\mathrm{PER}}$ & Celenza et al. (2006) \\
\hline PER-1-R & TTAATTTGGGCTTAGGG & & & \\
\hline PER-2-F & ATGAATGTCATCACAAAATG & $927(49)$ & & Celenza et al. (2006) \\
\hline PER-2-R & TCAATCCGGACTCACT & & & \\
\hline tet $\mathrm{A}-\mathrm{F}$ & GTGAAACCCAACATACCCC & $887(50)$ & $\operatorname{tet}(\mathrm{A})$ & Van et al. (2008) \\
\hline tet $\mathrm{A}-\mathrm{R}$ & GAAGGCAAGCAGGATGTAG & & & \\
\hline tet $\mathrm{B}-\mathrm{F}$ & CCTTATCATGCCAGTCTTGC & $773(50)$ & $\operatorname{tet}(\mathrm{B})$ & Van et al. (2008) \\
\hline tet $\mathrm{B}-\mathrm{R}$ & ACTGCCGTTTTTTCGCC & & & \\
\hline $\operatorname{aadB}-\mathrm{F}$ & ATGGACACAACGCAGGTCGC & $534(55)$ & $\operatorname{aad} \mathrm{B}$ & Asadollahi et al. (2012) \\
\hline $\operatorname{aadB}-\mathrm{R}$ & TTAGGCCGCATATCGCGACC & & & \\
\hline $\operatorname{aadA}-\mathrm{F}$ & GTGGATGGCGGCCTGAAGCC & $320(55)$ & $\operatorname{aadA}$ & Asadollahi et al. (2012) \\
\hline $\operatorname{aadA}-\mathrm{R}$ & AATGCCCAGTCGGCAGCG & & & \\
\hline$r m t \mathrm{~B}-\mathrm{F}$ & ATGAACATCAACGATGCCCT & $769(55)$ & $r m t \mathrm{~B}$ & Yan et al. (2004) \\
\hline$r m t \mathrm{~B}-\mathrm{R}$ & СCTTCTGATTGGCTTATCCA & & & \\
\hline $\operatorname{arm} \mathrm{A}-\mathrm{F}$ & CAAATGGATAAGAATGATGTT & $774(55)$ & $\operatorname{arm} \mathrm{A}$ & Galimand et al. (2003) \\
\hline $\operatorname{arm} \mathrm{A}-\mathrm{R}$ & TTATTTCTGAAATCCACT & & & \\
\hline $\operatorname{aph} \mathrm{A} 1-\mathrm{F}$ & AAACGTCTTGCTCGAGGC & $461(55)$ & $\operatorname{aph} \mathrm{A} 1$ & Weill et al. (2004) \\
\hline aphA1-R & CAAACCGTTATTCATTCGTGA & & & \\
\hline aacA4-F & ATGACTGAGCATGACCTTGCG & $487(55)$ & aacA4 & Odumosu et al. (2015) \\
\hline aacA4-R & TTAGGCATCACTGCGTGTTCG & & & \\
\hline $\operatorname{aac}(3) \mathrm{II}-\mathrm{F}$ & TGAAACGCTGACGGAGCCTC & $369(65)$ & $\operatorname{aac}(3) I I \quad \mathrm{Sa}$ & Sandvang and Aarestrup (2009) \\
\hline $\operatorname{aac}(3) \mathrm{II}-\mathrm{R}$ & GTCGAACAG GTAGCACTGAG & & & \\
\hline strA-F & CCTGGTGATAACGGCAATTC & $546(55)$ & strA & Lanz et al. (2003) \\
\hline strA-R & CCAATCGCAGATAGAAGGC & & & \\
\hline$s t r \mathrm{~B}-\mathrm{F}$ & ATCGTCAAGGGATTGAAACC & $509(55)$ & $s t r \mathrm{~B}$ & Lanz et al. (2003) \\
\hline strB-R & GGATCGTAGAACATATTGGC & & & \\
\hline catII-F & ACACTTTGCCCTTTATCGTC & $495(55)$ & $\operatorname{cat} \mathrm{II}$ & Vassort-Bruneau et al. (1996) \\
\hline catII-R & TGAAAGCCATCACATACTGC & & & \\
\hline$c m l A-F$ & TTGCAACAGTACGTGACAT & $293(55)$ & cmlA & Keyes et al.(2000) \\
\hline cmlA-R & ACACAACGTGTACAACCAG & & & \\
\hline sull-F & TTCGGCATTCTGAATCTCAC & $822(55)$ & sul1 & Cristabel et al. (2012) \\
\hline sull-R & ATGATCTAACCCTCGGTCTC & & & \\
\hline
\end{tabular}


Table 1 (continued). Antimicrobial resistance genes tested and oligonucleotide primers used in the study.

\begin{tabular}{|c|c|c|c|c|}
\hline Primer name & Sequence $\left(5^{\circ}-3^{`}\right)$ & , bp and $\mathrm{t}\left({ }^{\circ} \mathrm{C}\right)$ & Target gene & Source \\
\hline sul2-F & CGGCATCGTCAACATAACC & $722(50)$ & sul2 & Saenz et al. (2004) \\
\hline sul2-R & GTGTGCGGATGAAGTCAG & & & \\
\hline sul3-F & GAGCAAGATTTTTGGAATCG & $792(51)$ & sul3 & Parreten et al. (2003) \\
\hline sul3-R & CATCTGCAGCTAACCTAGGGCTTTGA & & & \\
\hline$d f r l-\mathrm{F}$ & ACGGATCCTGGCTGTTGGTTGGACGC & $254(55)$ & $d f r 1$ & Gibreel and Skold (1998) \\
\hline$d f r 1-\mathrm{R}$ & CGGAATTCACCTTCCGGCTCGATGTC & & & \\
\hline$d f r 5-\mathrm{F}$ & GCBAAAGGDGARCAGCT & $394(44)$ & $d f r 5$ & Šeputienè et al. (2010) \\
\hline$d f r 5-\mathrm{R}$ & TTTMCCAYATTTGATAGC & & & \\
\hline dfra7-F & AAAATTTCATTGATTTCTGCA & $471(44)$ & $d f r 7$ & Navia et al. (2003) \\
\hline dfrA7-R & TTAGCCTTTTTTCCAAATCT & & & \\
\hline
\end{tabular}

Other authors have reported data about resistant E. coli isolates obtained from different bird species including Canada geese, common buzzards, black kites, red kites, white-tailed eagles and goshawks (Middleton et al. 2005; Guenther et al. 2010; Radhouni et al. 2012). The main resistance patterns of the isolates in the above-mentioned studies were resistance combination to ampicillin, streptomycin, and sulphonamides. In Lithuania, the most important species carrying multi-resistant $E$. coli strains were herring gulls, blackheaded gulls, rooks, hooded crows as well as waterfowl, in particular mallards and mute swans. Such data contradict the results of a previous study performed in Portugal where $E$. coli isolated from similar species were susceptible to most of the antimicrobials tested (Radhouani et al. 2010). In another study performed by Dolejska et al. (2007) in the Czech Republic, the rate of resistant isolates from black-headed gulls to at least one antimicrobial was $29.2 \%$ whereas $6.2 \%$ of the isolates were treated as multi-resistant ones.

There is evidence that international human travelling is one of the causes of the spread of multi-resistant E. coli worldwide (Peirano and Pitout 2010). Considering that migratory bird species, particularly gulls, are often carriers of multi-resistant bacteria, it might be assumed that they also pose a risk for the dissemination of multi-resistant isolates throughout different countries or regions. The recent discovery of colistin-resistant $E$. coli harbouring plasmid-mediated $m e c-1$ gene in herring gulls in Europe (Ruzauskas and Vaskevičiute 2016) and in kelp gulls in South America (Liakopoulos et al. 2016) proves this opinion. The number of migrating birds worldwide has been estimated to be five billion a year (Berhold 2001) so the risk degree for the spread intensity of resistant bacteria is still undervalued. Beta-lactam antibiotics are the most frequently prescribed antibiotics worldwide to treat bacterial infections (Fernández-Aguadob et al. 2014). Therefore, it is not surprising that resistance to this class of antimicrobial agents poses increasingly complex problems for physicians. Extended-spectrum betalactamases (ESBLs) are a rapidly evolving group of beta-lactamases which share the ability to hydrolyze third-generation cephalosporins and aztreonam but are inhibited by clavulanic acid (Philippon et al. 1989). Our results demonstrated high rates of E. coli resistance to the $3^{\text {rd }}$ generation of cephalosporins and aztreonam. The bla ${ }_{\text {Стх-м }}$ gene was detected in $63.2 \%$ of the isolates resistant to the $3^{\text {rd }}$ generation of cephalosporins.

The use of sulphonamides was restricted for food animals in the 1980s after a potential threat to human health from residues in foods of animal origin, and they are currently approved for use in treating calf scours. Resistance to sulphonamides is plasmid mediated but chromosomal mutations for sulphonamide resistance take place very slowly (Prescott et al. 2013). Different genes encoding resistance to this antimicrobial are already described. 
Table 3. Presence of the tested genes encoding antimicrobial resistance in $E$. coli isolated from wild birds.

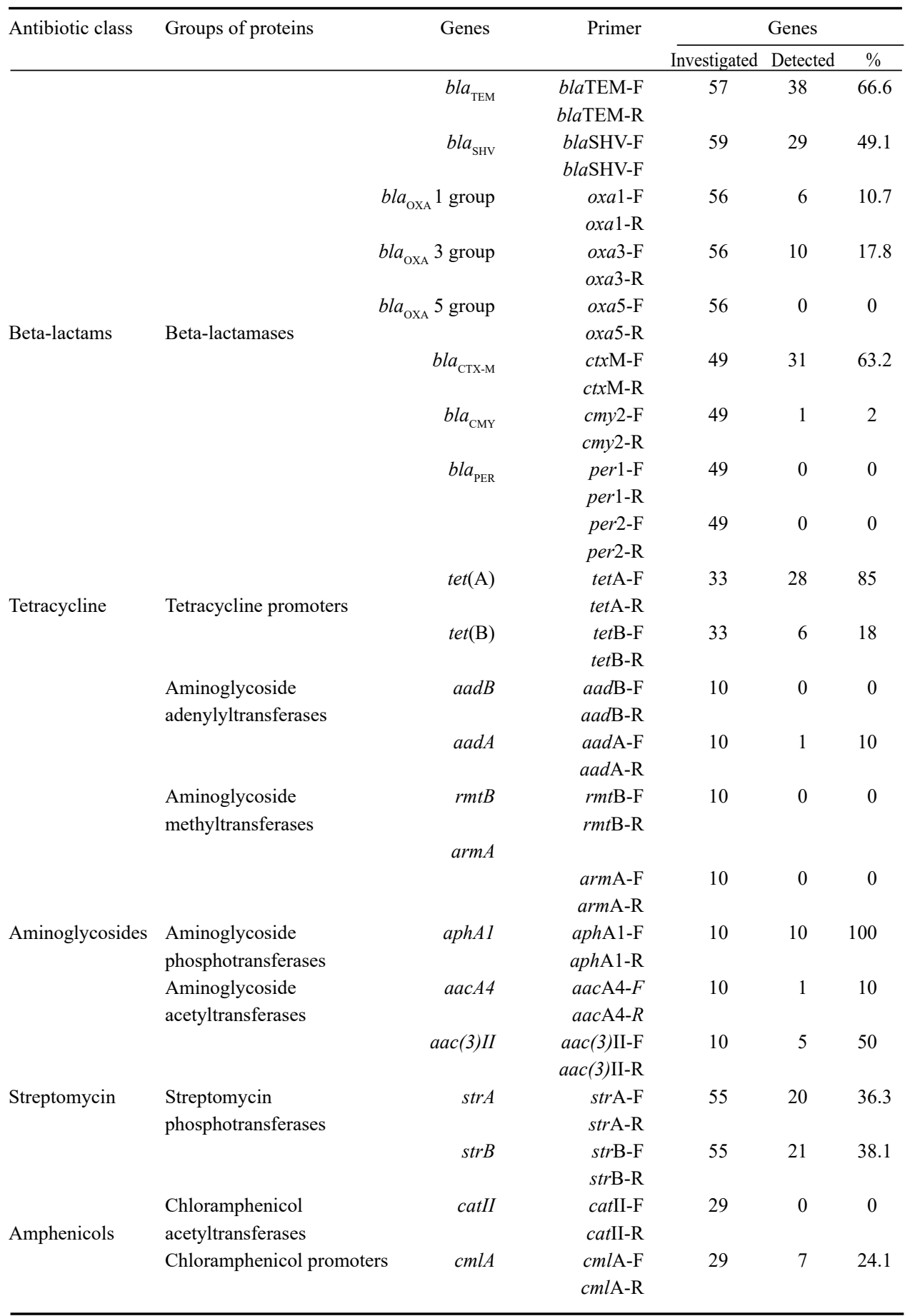


Table 3 (continued). Presence of the tested genes encoding antimicrobial resistance in $E$. coli isolated from wild birds.

\begin{tabular}{|c|c|c|c|c|c|c|}
\hline \multirow[t]{2}{*}{ Antibiotic classes } & \multirow[t]{2}{*}{ Groups of proteins } & \multirow[t]{2}{*}{ Genes } & \multirow[t]{2}{*}{ Primer } & \multicolumn{3}{|c|}{ Genes } \\
\hline & & & & Investigated & Detected & $\%$ \\
\hline & & sull & $\begin{array}{l}\text { sul1-F } \\
\text { sul1-R }\end{array}$ & 49 & 11 & 22.4 \\
\hline \multirow[t]{3}{*}{ Sulphonamides } & Dihydropteroate synthases & sul2 & $\begin{array}{l}\text { sul2-F } \\
s u l 2-\mathrm{R}\end{array}$ & 49 & 25 & 51 \\
\hline & & sul3 & $\begin{array}{l}s u l 3-\mathrm{F} \\
s u l 3-\mathrm{R}\end{array}$ & 49 & 23 & 46.9 \\
\hline & & $d f r l$ & $\begin{array}{l}d f r 1-\mathrm{F} \\
d f r 1-\mathrm{R}\end{array}$ & 13 & 2 & 15.3 \\
\hline \multirow[t]{2}{*}{ Trimethoprim } & Dihydrofolate reductase & $d f r 5$ & $\begin{array}{l}d f r 5-\mathrm{F} \\
d f r 5-\mathrm{R}\end{array}$ & 13 & 11 & 84.6 \\
\hline & & $d f r 7$ & $\begin{array}{l}d f r 7-\mathrm{F} \\
d f r 7-\mathrm{R}\end{array}$ & 13 & 2 & 15.3 \\
\hline
\end{tabular}

For instance, sul 3 has been detected in E. coli isolates from different animals in Switzerland and Germany (Guerra et al. 2003; Perreten et al. 2003) while sull was the most prevalent among human isolates (Hammerum et al. 2006). Our study demonstrated that different sul genes were prevalent in E. coli carried by wild birds including sul1, sul2 and sul3, therefore, it suggests the possibility for birds to acquire antimicrobial resistant bacteria from different sources, including domestic animals and contaminated environment.

Tetracycline-resistance now occurs in anincreasing number of pathogenic, opportunistic, and commensal bacteria. Tetracycline-resistance is often due to the acquisition of new genes, which code for energy-dependent efflux of tetracyclines or for a protein that protects bacterial ribosomes from the action of tetracyclines. A limited number of bacteria acquire resistance by mutations, which alter the permeability of the outer membrane porins and/or lipopolysaccharides in the outer membrane, change the regulation of innate efflux systems, or alter the 16S rRNA (ribosomal ribonucleic acid) (Chopra and Roberts et al. 2001). The detection of tetA gene in almost $85 \%$ of tetracycline-resistant isolates in our study shows that the main mechanism of tetracycline resistance in E. coli isolates from wild birds is by active efflux. Similar results were published by Dolejska et al. (2007) where both tetA and tet $\mathrm{B}$ genes were detected in $E$. coli isolates.

This study demonstrated that wild birds, particularly those living in the urban enviroment are carriers of antibiotic resistant bacteria. These bacteria are often resistant to different classes of antimicrobials including those that are critically important for humans aminoglycosides, aminopenicillins and fluoroquinolones. Moreover, microbiota of wild birds share the same antimicrobial resistance genes that are important in aquired resistance of bacteria prevalent in humans and domestic animals. It is still unclear whether $E$. coli prevalent in birds can colonize humans and domestic animals but there are some studies that show a possible zoonotic transfer of similar E. coli strains among different hosts (Van den Bogaard et al. 2013).

Control measures for disposal of antibiotics should be tightened as residues of antimicrobials and resistant bacteria from the environment can be passed onto wild birds.

\section{Conflict of Interests}

The authors declare that they have no competing interests. 


\section{Acknowledgements}

The study was funded by a grant (SIT-6/2015) from the Research Council of Lithuania.

\section{References}

Asadollahi P, Akbari M, Soroush S, Taherikalani M, Asadollahi K, Sayehmiri K 2012: Antimicrobial resistance patterns and their encoding genes among Acinetobacter baumannii strains isolated from burned patients. Clin Infect Dis 38: 1198-1203

Benskin CH, Wilson K, Jones K, Hartley IR 2009: Bacterial pathogens in wild birds: a review of the frequency and effects of infection. Cambridge: Philosophical Society, pp 349-373

Berthold P 2001: Bird Migration. a General Survey. Oxford Ornithological Series $2^{\text {nd }}$ edn. Oxford Univ. Press Oxford, Great Britain pp 14-16

Bert F, Branger C, Lambert-Zechovsky N 2002: Identification of PSE and OXA $\beta$-lactamase genes in Pseudomonas aeruginosa using PCR-restriction fragment length polymorphism. J Antimicrob Chemoth 50: 11-18

Celenza G, Pellegrini C, Caccamo M, Segatore B, Amicosante G, Perilli M 2006: Spread of blaCTX-M-type and blaPER-2 $\beta$-lactamase genes in clinical isolates from Bolivian hospitals. J Antimicrob Chemoth 57: $975-978$

Chopra I, Roberts M 2001: Tetracycline Antibiotics: Mode of Action, Applications, Molecular Biology, and Epidemiology of Bacterial Resistance. Microbiol Mol Biol R 65: 2232-2260

Christabel M, Budambula N, Kiiru J, Kariuki S 2012: Characterization of antibiotic resistance in environmental enteric pathogens from Kibera slum in Nairobi-Kenya. Afr J Bacteriol Res 4: 46-54

Clinical and Laboratory Standards Institute. Performance Standards for Antimicrobial Disk and Dilution Susceptibility Test for Bacteria Isolated From Animals. 3rd 2015: CLSI supplement VET01S. USA, Wayne, Pennsylvania: Clinical and Laboratory Standards Institute, pp 23-25

Dolejska M, Cizek A, Literak I 2007: High prevalence of antimicrobial-resistant genes and integrons in Escherichia coli isolates from Black-headed Gulls in the Czech Republic. J Appl Microbiol 103: 11-19

Fernández-Aguado M, Martín JF, Rodríguez-Castro R, García-Estrada C, Albillos SM, Teijeira LF, Ullán RV 2014: New insights into the isopenicillin N transport in Penicillium chrysogenum. Metab Eng 22: 89-103

Fogarty LR, Haack SK, Wolcott MJ, Whitman RL 2003: Abundance and characteristics of the recreational water quality indicator bacteria Escherichia coli and enterococci in gull faeces. J Appl Microbiol 94: 865-878

Galimand M, Courvalin P, Lambert T 2003: Plasmid-mediated high-level resistance to aminoglycosides in Enterobacteriaceae due to $16 \mathrm{~S}$ rRNA methylation. Antimicrob Agents Ch 47: 2565-2571

Gibreel A, Sköld O 1998: High-level resistance to trimethoprim in clinical isolates of Campylobacter jejuni by acquisition of foreign genes ( $d f r l$ and $d f r 9$ ) expressing drug-insensitive dihydrofolate reductases. Antimicrob Agents Ch 42: 3059-3064

Guenther S, Aschenbrenner K, Stamm I, Stubbe A, Stubbe M, Batsajkhan N, Glupczynski Y, Wieler LH, Ewers C 2012: Comparable high rates of extended-spectrum-betalactamase-producing Escherichia coli in birds of prey from Germany and Mongolia. PLoS One 7: 53039

Guenther S, Grobbel M, Heidemanns K, Schlegel M, Ulrich R G, Ewers C, Wieler LH 2010: First insights into antimicrobial resistance among faecal Escherichia coli isolates from small wild mammals in rural areas. Sci Total Environ 408: 3519-3522

Guerra B, Junker E, Schroeter A, Malorny B, Lehmann S, Helmuth R 2003: Phenotypic and genotypic characterization of antimicrobial resistance in German Escherichia coli isolates from cattle, swine and poultry J Antimicrob Chemoth 523: 489-492

Hatch JJ 1996: Threat to public health from gulls. Int J Environ Health 6: 5-16

Hammerum AM, Sandvang D, Andersen SR, Seyfarth AM, Porsbo LJ, Møller NF, Heuer OE 2006: Detection of sull, sul2 and sul3 in sulphonamide resistant Escherichia coli isolates obtained from healthy humans, pork and pigs in Denmark. Inter J Food Microbiol 106: 235-237

Hasman H, Mevius D, Veldman K, Olesen I, Aarestrup F M 2005: $\beta$-Lactamases among extended-spectrum $\beta$-lactamase (ESBL)-resistant Salmonella from poultry, poultry products and human patients in The Netherlands. J Antimicrob Chemoth 56: 115-121

Keyes K, Hudson C, Maurer JJ, Thayer S, White DG, Lee MD 2000: Detection of florfenicol resistance genes in Escherichia coli isolated from sick chickens. Antimicrob Agents Ch 44: 421-424

Lanz R, Kuhnert P, Boerlin P 2003: Antimicrobial resistance and resistance genes determinants in clinical Escherichia coli from different animal species in Switzerland. Vet Microbiol 91: 73-84

Liakopoulos A, Mevius DJ, Olsen B 2016: The colistin resistance $m c r-1$ gene is going wild. J Antimicrob Chemoth 71: 233-236

Middleton J, Ambrose HA 2005: Enumeration and antibiotic resistance patterns of faecal indicator organisms isolated from migratory Canada geese (Branta canadensis). J Wildl Dis 41: 334-341

Moore JE, Gilpin D, Crothers E, Canney A, Kaneko A, Matsuda M 2002: Occurrence of Campylobacter spp. and Cryptosporidium spp. in seagulls (Larus spp.). Vector Borne Zoonotic Dis 2: 111-114 
Navia MM, Ruiz J, Cespedes SJ, Vila J 2003: Detection of dihydrofolate reductase genes by PCR and RFLP. Diagn Microbiol Infect Dis 46: 295-298

Nelson M, Jones SH, Edwards C, Ellis JC 2008: Characterization of Escherichia coli population from gulls, landfill trach, and wastewater using ribotyping. Dis Aquat Organ 81: 53-63

Odumosu BT, Akintimehin AR 2015: Occurrence of extended-spectrum beta-lactamase producing Enterobacteriaceae isolates in communal water sources in Ogun State, Nigeria. Afr J Clin Exp Microbiol 16: 28-32

Ojdana D, Sacha PB, Wieczorek P, Czaban B, Michalska A, Jaworowska J, Jurczak A, Poniatowski B, Tryniszewska E 2014: The occurrence of blaCTX-M, blaSHV, and blaTEM genes in extended-spectrum $\beta$-lactamase-positive strains of Klebsiella pneumoniae, Escherichia coli, and Proteus mirabilis in Poland. Int J Antibiot 2: 6-7

Pagani L, Dell'Amico E, Migliavacca R, D’Andrea MM, Giacobone E, Amicosante G, Rossolini GM 2003: Multiple CTX-M-type extended-spectrum $\beta$-lactamases in nosocomial isolates of Enterobacteriaceae from a hospital in Northern Italy. J Clin Microbiol 41: 4264-4269

Philippon A, Labia R, Jacoby G 1989: Extended-spectrum beta-lactamases. Antimicrob Agents Ch 33: $1131-1136$

Peirano G, Pitout JD 2010: Molecular epidemiology of Escherichia coli producing CTX-M beta-lactamases: the worldwide emergence of clone ST131 O25:H4. Int J Antimicrob Agents 35: 316-321

Perreten V, Boerlin PA 2003: New sulfonamide resistance gene (sul3) in Escherichia coli is widespread in the pig population of Switzerland. Antimicrob Agents Ch 44: 1169-1172

Prescott JF, Baggot JD, Walker RD 2013: Antimicrobial therapy in veterinary epidemiology. $3^{\text {rd }}$ edn. Iowa State University Press, Ames, pp 110-116

Quessy S, Messier S 1992: Prevalence of Salmonella spp., Campylobacter spp. and Listeria spp. in ring-billed gulls (Larus delawarensis). J Wildl Dis 28: 526-531

Radhouni H, Poeta P, Goncalves A, Pacheco R, Sargo R, Igrejas G 2012: Wild birds biological indicators of environmental pollution: antimicrobial resistance patterns of Escherichia coli and enteroccoci isolated from common buzzards (Buteo buteo). J Med Microbiol 61: 837-843

Radhouani H, Poeta P, Igrejas G, Goncalves A, Vinue L, Torres C 2009: Antimicrobial resistance and phylogenetic groups in isolates of Escherichia coli from seagulls at the Berlengas nature reserve. Vet Rec 165: 138-142

Ružauskas M, Vaškevičiūtė L 2016: Detection of the mcr-1 gene in Escherichia coli prevalent in the migratory bird species Larus argentatus. J Antimicrob Chemoth 71: 2333-2334

Sandvang D, Aarestrupp FM 2009: Characterization of aminoglycoside resistance genes and class 1 integrons in porcine and bovine gentamicin-resistant Escherichia coli. Microb Drug Resist 6: 19-27

Šeputienė V, Povilonis J, Ružauskas M, Pavilonis A, Sužiedėlienė E 2010: Prevalence of trimethoprim resistance genes in Escherichia coli isolates of human and animal origin in Lithuania. J Med Microbiol 59: 315-322

van Den Bogaard AE, London N, Driessen C, Stobberingh EE 2001: Antibiotic resistance of faecal Escherichia coli in poultry, poultry farmers and poultry slaughterers. J Antimicrob Chemoth 47: 763-771

Van T T, Chin J, Chapman T, Tran LT, Coloe PJ 2008: Safety of raw meat and shellfish in Vietnam: An analysis of Escherichia coli isolations for antibiotic resistance and virulence genes. Int J Food Microbiol 3: 217-223

Vassort-Bruneau C, Lesage-Descauses MC, Martel JL, Lafont JP, Chaslus-Dancla E 1996: CAT III chloramphenicol resistance in Pasteurella haemolytica and Pasteurella multocida isolated from calves. J Antimicrob Chemoth 38: $205-213$

Waldenström J, Ottvall R, Hasselquist D, Harrington CS, Olsen B 2003: Avian reservoirs and zoonotic potential of the emerging pathogen Helicobacter canadensis. Appl Environ Microbiol 69: 7523-7526

Wasinski B, Rozanska H, Osek J 2013: Occurrence of extended spectrum $\beta$-lactamase and AmpC-producing Escherichia coli in meat samples. Bull Vet Inst Pulawy 57: 513-517

Weill FX, Demartin M, Tandé D, Espié E, Rakotoarivony I, Grimont PA 2004: SHV-12-like extended-spectrum$\beta$-lactamase-producing strains of Salmonella enterica serotypes Babelsberg and Enteritidis isolated in France among infants adopted from Mali. J Clin Microbiol 42: 2432-2437

Yan JJ, Wu JJ, Ko WC, Tsai SH, Chuang CL, Wu HM, Lu YJ, Li JD 2004: Plasmid-mediated 16S rRNA methylases conferring high-level aminoglycoside resistance in Escherichia coli and Klebsiella pneumoniae isolates from two Taiwanese hospitals. J Antimicrob Chemoth 54: 1007-1012 
Plate II

Merkeviciene L. et al.: Prevalence and ... pp. 9-17

Table 2. Minimal inhibitory concentration distributions for multi-resistant $E$. coli isolates from wild birds $(\%),(n=60)$.

\begin{tabular}{lllllllllll}
\hline Antimicrobial & \multicolumn{1}{c}{ MIC distributions (\%) (mg/1) } \\
\cline { 2 - 9 } & 0.5 & 1 & 2 & 4 & 8 & 16 & 32 & 64 & 128
\end{tabular}

\begin{tabular}{|c|c|c|c|c|c|c|c|c|c|}
\hline Amikacin & & & & & 100 & 0 & 0 & 0 & \\
\hline Ampicillin & & & & 18 & 0 & 2 & 80 & & \\
\hline Ampicillin/Sulbactam & & & & 26 & 6 & 26 & 42 & & \\
\hline Aztreonam & & & & & 60 & 8 & 32 & & \\
\hline Cefazolin & & & & 34 & 3 & 3 & 60 & & \\
\hline Cefepime & & & & 88 & 2 & 5 & 5 & & \\
\hline Cefoxitin & & & & 56 & 12 & 5 & 27 & & \\
\hline Cefpodoxime & & & 38 & 5 & 2 & 55 & & & \\
\hline Ceftazidime & & 54 & 12 & 8 & 18 & 3 & 5 & & \\
\hline Ceftriaxone & & 45 & 0 & 8 & 7 & 3 & 12 & 25 & \\
\hline Cefuroxime & & & & 37 & 3 & 7 & 53 & & \\
\hline Ciprofloxacin & 53 & 5 & 42 & 0 & & & & & \\
\hline Gentamicin & & & 83 & 0 & 0 & 17 & & & \\
\hline Imipenem & & & 95 & 0 & 2 & 3 & & & \\
\hline Nitrofurantion & & & & & & 82 & 7 & 3 & 8 \\
\hline Ticarcillin/Clavulanic acid & & & & & & 74 & 8 & 18 & \\
\hline Tobramycin & & & & 88 & 12 & & & & \\
\hline Trimethoprim/Sulfamethoxazole & 51 & 5 & & 22 & 22 & & & & \\
\hline
\end{tabular}

Green cells - susceptible; yellow - intermediate; red cells - resistant

MIC - minimal inhibitory concentration 